\title{
Diskursus Politik Islam dan Kebijakan Ideologis Media Massa di Sumatera Utara
}

\author{
Nirwansyah Putra, Faizal Hamzah Lubis *) \\ Program Studi Ilmu Komunikasi, Universitas Muhammadiyah Sumatera Utara, Indonesia \\ Koresponden: nirwansyahputra@umsu.ac.id; \\ faizalhamzah@umsu.ac.id
}

\begin{abstract}
Abstrak
Stigmatisasi dan labelisasi terhadap imej Islam di media memerlihatkan wacana islamophobia, terorisme, radikalisme hingga fundamentalisme. Di sisi lain, kapitalisasi-industrialisasi media dan perkembangan teknologi komunikasi informasi yang pesat, telah meneguhkan ketergantungan media-media di tingkat lokal ke level nasional dan internasional semakin tinggi. Penyebaran wacana Islam berjalan secara sepihak, terusmenerus dan massif, seperti propaganda. Untuk menyusuri masalah ini, digunakan pendekatan historiskomparatif dan ekonomi-politik. Studi ini memerlihatkan diskursus politik Islam di media merupakan gambaran politik Islam yang terbelah pada pemahaman holistik dan sekuler. Ketiadaan media yang berkonsentrasi pada politik Islam, dan lebih memilih segmentasi umum-sekuler, membuat agenda politik Islam tergantung pada pertimbangan ideologis pemilik dan pilihan segmentasi pasar.
\end{abstract}

Kata Kunci: Industralisasi-Kapitalisasi Media, Politik Islam, Kebijakan Media

\begin{abstract}
Stigmatization and labeling of the Islamic image in the media shows the discourse of Islamophobia, terrorism, radicalism to fundamentalism. On the other hand, the capitalization-industrialization of the media and the rapid development of information communication technology, has strengthened the dependency of the media at the local level to the national and international levels. The spread of Islamic discourse runs unilaterally, continuously and massively, like propaganda. To explore this problem, a historical-comparative and economic-political approach is used. This study shows that Islamic political discourse in the media is a picture of Islamic politics which is divided into holistic and secular understandings. The absence of a media that concentrates on Islamic politics, and prefers general-secular segmentation, makes the Islamic political agenda in the media, depend on the ideological considerations of the owner and the choice of market segmentation.
\end{abstract}

Keyword: Media Industrialization-Capitalism, Islamic Politics, Media Policy

\section{Pendahuluan}

Term Islamophobia sebagai sebuah streotype ataupun streotype itu sendiri, barangkali adalah topik yang paling mudah dimasukkan dalam melihat beragam hubungan antara politik Islam dan media, terutama di Eropa dan Amerika Serikat (AS). Tidak mudah untuk menyisihkan istilah ini apalagi ketika hal-hal seperti terorisme, radikalisme hingga fundamentalisme menjadi bingkai khusus dari media dalam melihat Islam dan umat Islam akhir-akhir ini. Tidak dapat dipungkiri kalau peristiwa hancurnya World Trade Center di New York pada 9 September 2001 yang membuat AS mengumandangkan war on terror di seluruh dunia, menjadi semacam pemicu baru hubungan yang cenderung negatif antara media barat dengan Islam dan muslim. Perang itu dipahamkan dalam arti yang sangat luas dan tidak sekedar perang fisik dalam bentuk militer semata.

Di sisi yang lain, kapitalisasi dan konglomerasi yang melanda media, termasuk perkembangan teknologi komunikasi dan informasi yang begitu dahsyat, telah mengakibatkan dependensi media-media di tingkat lokal ke level nasional dan seterusnya ke media transnasional, semakin kukuh. Hal ini menyebabkan penyebaran wacana 
mengenai imej Islam yang berjalan secara sepihak dalam iklim globalisasi informasi tak dapat lagi dibedakan dengan suatu kisah propaganda yang dilakukan secara terus-menerus dan massif.

Gambaran yang dinilai buruk ini, oleh internal umat Islam seringkali dianggap sebagai bagian dari sebuah konspirasi. Walau harus dicatat, apa yang dituduhkan sebagai "konspirasi" itu hampir-hampir tidak dapat dibuktikan kebenarannya. Namun pada sisi sebaliknya, peperangan diskursus, stigmatisasi dan labelisasi imej Islam, tidak dapat pula dengan mudah dapat diterangkan dalam konsepsi umum media mengenai independensi, objektivitas dan nilai-nilai moral dari pers mengenai kebenaran, kejujuran dan keadilan.

Media bukan barang mati. Media adalah sebuah ruang di mana berbagai ideologi direpresentasikan ${ }^{1}$. Ini berarti di satu sisi media bisa menjadi sarana penyebaran ideologi penguasa, alat legitimasi dan kontrol atas wacana publik. Namun di sisi lain, media bisa menjadi alat resistensi terhadap kekuasaan (ideological state apparatus). Kesimpulannya adalah media massa bukan sesuatu yang bebas, independen, tetapi memiliki keterkaitan dengan realitas sosial karena berbagai kepentingan yang bermain dalam media massa.

Studi ini adalah studi kualitatif dengan menggunakan pendekatan historiskomparatif dan ekonomi-politik dalam analisis dan interpretasi kualitatif. Argumennya adalah, peristiwa yang terjadi belakangan dapat ditengarai sebagai satu rangkaian yang tak pula dapat dipisahkan begitu saja. Pendekatan ekonomi-politik menjadikan kajian ini mengarah pada analisis komparatif terhadap gagasan dan praktik para pemilik dan pekerja di media massa, intelektual dan politisi muslim dari beberapa generasi yang berbeda, disertai pertimbangan konteks kekuatan sosial politik ekonomi di wilayah yang menjadi objek studi.

Ada tiga faktor pendekatan yang mempengaruhi sebuah media massa dalam mengkonstruksikan realitas, antara lain pendekatan politik-ekonomi di luar pengelolaan media, pendekatan organisasi serta pendekatan kulturalis (Eriyanto, 2005:67)

\section{Gambar 1. Organisasi Media di Tengah Kekuatan Sosial}

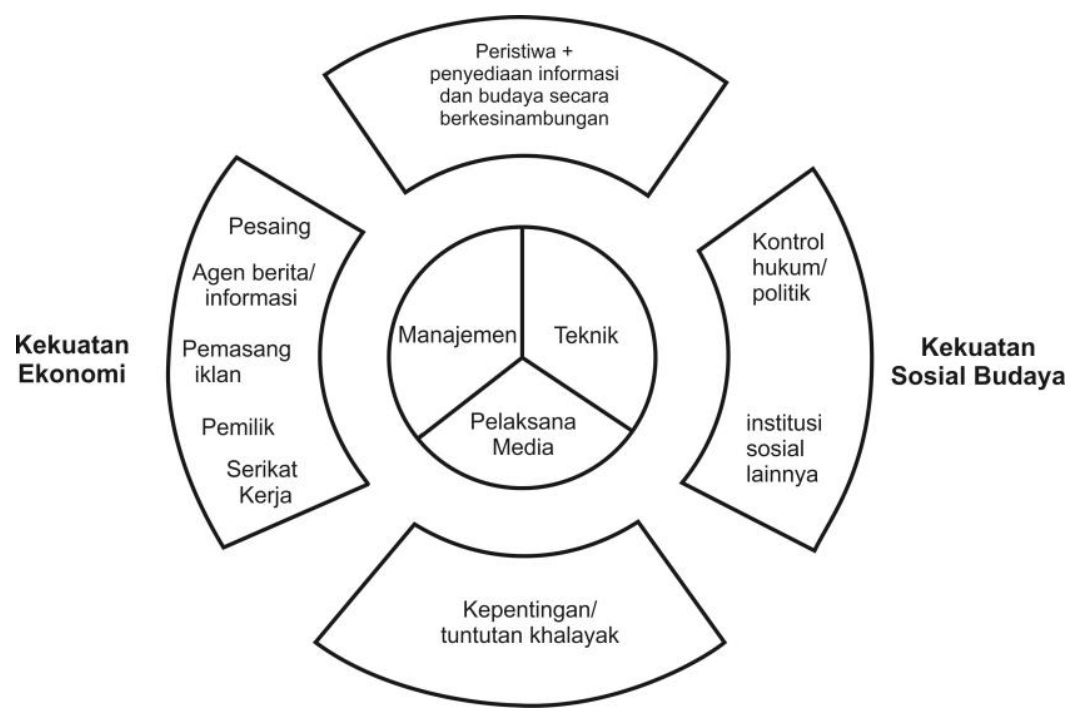

Sumber: McQuail (2001:103) 
Pendekatan politik ekonomi berpendapat bahwa isi media lebih ditentukan oleh kekuatan-kekuatan politik dan ekonomi di luar pengelolalan media. Menurut Agus Sudibyo (2006:65), faktor seperti pemilik media, modal dan pendapatan media (serta segmen pembaca) dianggap lebih menentukan bagaimana wujud isi media. Pendekatan organisasi justru melihat pengelola media sebagai pihak yang aktif dalam proses pembentukan dan produksi berita. Dalam pendekatan ini, berita dilihat sebagai hasil dari mekanisme yang ada dalam ruang redaksi. Praktik kerja, profesionalisme dan tata aturan (ideologi) yang ada dalam ruang orgaisasi adalah unsur-unsur dinamik yang mempengaruhi pemberitaan. Pendekatan kulturalis merupakan gabungan antara pendekatan ekonomi politik dan pendekatan organisasi. Proses produksi berita di sini dilihat sebagai mekanisme yang rumit yang melibatkan faktor internal sekaligus eksternal media.

\section{Pers Islam dan Etik}

Bagaimana mendefinisikan pers Islam? Dari segi teknis, pada dasarnya tidak ada perbedaan mencolok antara pers umum dan pers Islam karena teknis jurnalistik dalam pers umum juga diwajibkan untuk sesuai dengan Kode Etik Jurnalistik (KEJ) yang bersifat universal. Adanya istilah-istilah yang diperkenalkan dunia Islam seperti tabayyun, pada prinsipnya tidaklah berbeda dengan konsepsi cek-ricek-kroscek, perimbangan informasi dan narasumber serta independensi jurnalis, dalam konsepsi pers umum yang sudah berlaku selama ini, baik di Indonesia maupun di dunia internasional. Ketika etik jurnalistik diperiksa, apakah lewat Kode Etik Wartawan Indonesia (KEWI) ala Dewan Pers, kode etik PWI, AJI dan organisasi pers lainnya, sampai pada Sembilan Elemen Jurnalisme yang disusun Bill Kovach dan Tom Rosenstiel yang menjadi nilai-nilai pokok kebanyakan wartawan Amerika dan Eropa, maka nilai-nilai universal yang disepakati bersama itu, akan kelihatan dengan jelas. Misalnya soal kebenaran informasi yang menjadi pasal pertama dari ketiga etik yang disebutkan di atas.

Pada pers Islam, maka titik utama persoalan nilai-nilai etik haruslah berdasarkan Islam. Walau memang disadari, penafsiran terhadap Islam tidaklah bersifat monopolis. Namun, pencarian dan perumusan terhadap kode etik jurnalisme Islam justru hingga kini belum bisa ditemukan secara pasti. Kalaupun di negara-negara yang populasi muslim terbesar juga berkembang industri pers, namun landasan etik Islami, toh, masih absen.

Pada pertemuan Asian Islamic Confrence yang dihelat Lima Muslim Dunia di Karachi, Pakistan pada 1978, niat untuk merumuskan itu sudah ada namun ternyata pertemuan itu lebih pada menyatukan perspektif para jurnalis Islam untuk menghadapi monopoli media barat dan propaganda anti-Islam.

Pada tahun 1979, Organisasi Konferensi Islam (OKI) membentuk International Islamic News Agency (IINA) yang bermarkas di Jeddah, Arab Saudi. Namun tujuan IINA tidaklah sampai pada mengkonsolidasikan etik jurnalisme Islam. Pada pertemuan International Confrence of Muslim Journalist di Jakarta, pada 1-3 September 1981, yang menghasilkan Islamic Mass Media Charter, pun belum terasa konkrit terimplementasi hingga kini. Karena itu, persoalan definisi mengenai pers Islam tidaklah mudah. Yang paling dapat dilakukan untuk membatasi soal ini adalah pers Islam dapat dilihat pada tiga hal:

1. Pers yang didirikan muslim ataupun kelompok Islam.

2. Pers yang diisi oleh praktisi jurnalistik muslim.

3. Pers yang menyuarakan kepentingan Islam. 
Bila poin pertama merujuk langsung pada media massa yang khusus didirikan untuk menyuarakan Islam, maka pada poin 2 dan 3, media massa yang dimaksud lebih bersifat umum dan ketika didirikan memang tidak dimaksudkan secara spesifik menggolongkan diri sebagai pers Islam. Karena itu, eksistensi pers Islam dimaksudkan pada dua hal yaitu sebagai objek faktual dan sebagai nilai. Dengan demikian, mengatakan pers Islam sama sekali tidak eksis, akan bertentangan dengan fakta yang telah terjadi. Dalam hal ini, maka bila pers Islam ditujukan pada bentuk eksistensi objeknya, sementara yang lain yaitu sebagai "nilai", maka dalam kajian ini dia disebut pers Islami.

Sebagai catatan pada poin ke-2, walaupun media massa itu diisi oleh praktisi jurnalistik muslim namun belum tentu dia menyiarkan kepentingan Islam. Kepentingan Islam ini pun mesti dikaji lebih jauh dengan menggarisbawahi apakah informasi yang disiarkan itu masuk dalam kategori positif (membela), negatif (memojokkan) atau netral. Ini dengan perhitungan bahwa penyiaran peristiwa yang berkaitan dengan Islam tanpa tendesi apa-apa (apakah negatif atau positif), juga tergambar dalam pemberitaan media massa. Artinya, informasi yang disampaikan memang hanya sekedar informasi. Ini misalnya yang terjadi ketika peristiwa-peristiwa ritual keislaman, tata cara ibadah dan lain sebagainya yang bersifat rutinitas, berseliweran di media massa, baik pers Islam, islami maupun pers umum. Namun, yang disebut "netral" itu pun bisa dimasukkan dalam himpunan kategori positif, bila dia ditafsirkan dalam kerangka "syiar" atau penyebarluasan informasi mengenai keislaman, baik kepada pihak internal Islam maupun eksternal (kalangan non-muslim, masyrakat umum dan negara).

\section{Pers Islam, Basis Sosiologis, dan Kebijakan Media}

Bila diikuti dengan komposisi penduduk di Sumut yang sejak 1980 umat Islam sebagai mayoritas dengan persentase lebih dari 60\% (pada 1980 sebesar 61,38\% dan 2010 mencapai 66,08\%), maka komposisi ini dari segi segmentasi bisnis media menjadikan umat Islam sebagai pasar terbesar dari media.

Gambar 2. Komposisi Penduduk Sumut Berdasarkan Agama 2010

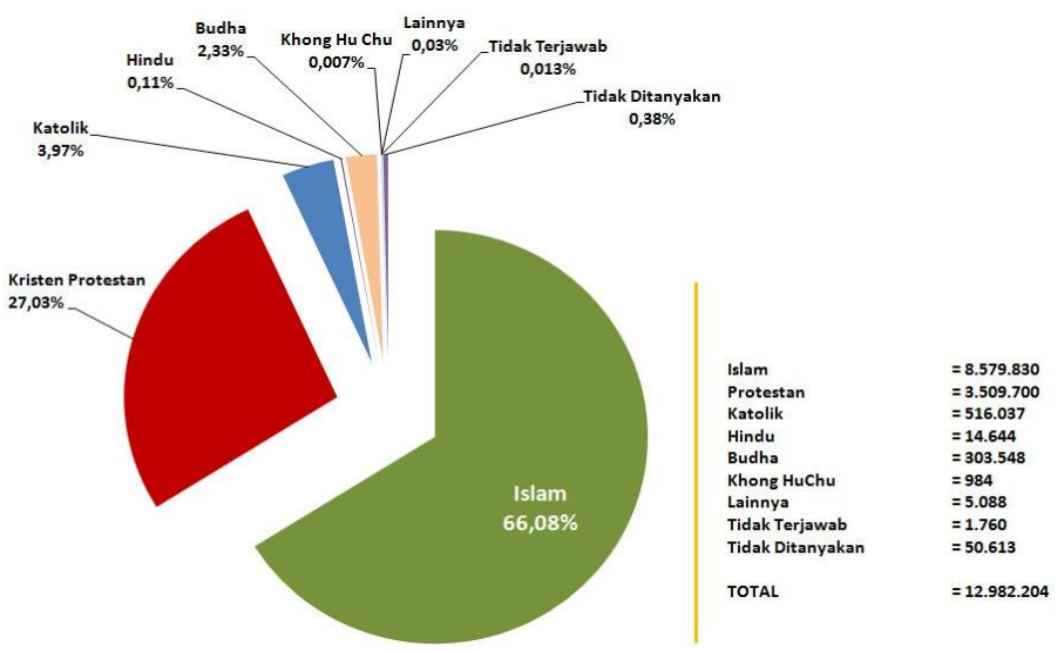

Sumber: Diolah dari data Sensus Penduduk 2010 
Tidaklah mengherankan bila pemilahan umat Islam sebagai pasar lebih dimungkinkan dari segi profit-oriented daripada segi ideologis. Karena itu, bersinggungan langsung secara negatif dengan umat Islam, akan sangat tidak menguntungkan bagi bisnis media. Ini tidak hanya berlaku bagi koran di Medan, tapi juga koran Jakarta yang beredar di Sumut. Harian Kompas misalnya. Harian yang didirikan oleh kelompok Katolik ini, juga membuat berita mengenai organisasi keislaman seperti Muhammadiyah dan Nahdhatul Ulama, serta tokoh-tokoh Islam baik dalam berita biasa maupun berita unggulannya.

Tapi masih ada unsur lain untuk melihat keberpihakan dari redaksi, yaitu pemilihan dan pemilahan berita yang akan ditampilkan. Harian Waspada tampak jelas memerlihatkan keberpihakannya kepada umat Islam di antaranya dengan meletakkan rubrik khusus di edisi Jumat. Begitupun, di saat-saat tertentu dalam perhelatan politik lokal, seperti saat pemilihan kepala daerah Kota Medan yang menghadapkan antara Rahudman Harahap dan Sofyan Tan, tampak jelas pemberitaan itu lebih mengarah ke hal yang positif kepada Rahudman Harahap, seorang calon dari kalangan muslim daripada Sofyan Tan yang nonmuslim.

Memang, pilihan strategi bisnis ini bukan hanya menampakkan keuntungan melainkan juga kerugian di sisi sebaliknya. Karena simpati justru tidak bisa diraih dari kalangan minoritas non-muslim. Begitu juga sebaliknya dengan media-media lain seperti Sinar Indonesia Baru (SIB) dan Analisa. Karena itu pula, pilihan segmentasi yang lebih umum dan di luar kotak agama, menjadi lebih aman.

Penjabaran lain soal segmentasi sosiologis ini bisa terlihat dari penelurusan terhadap harian Waspada. Karena lahir sejak 1947, koran ini mempunyai pembaca yang mereka sebut dengan pembaca tradisional. Pada awalnya, aliran politik pendiri Waspada yaitu Muhammad Said adalah nasionalis. Itu dikarenakan Muhammad Said dan Ani Idrus adalah anggota Partai Nasionalis Indonesia (PNI) yang didirikan oleh Soekarno. Namun, Waspada juga beredar luas di kawasan Islam lainnya di luar Sumut seperti Nanggroe Aceh Darussalam. Berita-berita agama Islam kemudian dibukukan baik dalam pemberitaan di halaman depan, penambahan porsi jumlah berita hingga pemuatan rubrik-rubrik khusus keislaman seperti Khutbah Jumat.

Memang, akan ada pertanyaan besar ketika melihat potensi pasar umat Islam yang mayoritas, mengapa oplah media yang memang dari awal mengusung soal Islam, seperti koran Republika yang didirikan oleh Ikatan Cendekiawan Muslim Indonesia (ICMI), tidak menjadi koran terbesar dari segi oplah di Indonesia. Apakah pilihan segmentatif seperti ini tidak menguntungkan dari segi bisnis?

Salah satu yang menjadi jawaban yang mungkin dapat diberlakukan di sini adalah tafsir terhadap Islam tidak bisa terlalu rigid atau kaku. Artinya, implementasi keislaman dalam bentuk peristiwa dan kemudian diliput dan ditafsir oleh kalangan media, tidak selalu dapat disamakan. Kalangan media umum pada dasarnya menginginkan adanya perluasan tafsir implementasi keislaman yang lebih dari sekedar aktivitas kontemporer, dan menginginkan adanya keluasan makna, nilai dan substansi keislaman yang lebih komprehensif. Misalnya, Islam tidak hanya diberitakan soal fiqh, shalat, puasa dan zakat tapi juga bidang-bidang lain yang merupakan nilai-nilai Islam, seperti ayat dan hadis yang berbicara tentang ekonomi, pertanian dan perindustrian.

Pandangan ini jelas bukan dalam kerangka sekuralisme melainkan menjabarkan keislaman secara komprehensif dan bukannya parsial. Karena itu, bagi kalangan jurnalis tertentu, sekulerisme bukan hanya sebuah masalah, melainkan juga sebuah tantangan bagi 
agama dan para tokoh dan ulama untuk bagaimana meningkatkan kualitas pemahaman agama para penganutnya.

Masalah lain adalah labeling terhadap Islam. Penanganan terorisme di masa reformasi memunculkan masalah baru bagi umat Islam yaitu kata "jihad". Diksi "jihad" yang menjadi salah satu terminologi resmi di ajaran Islam, justru menjadi perdebatan dan sering mengundang wacana apakah "pertempuran bersenjata" menjadi satu-satunya makna jihad bagi umat Islam. Apalagi, dunia barat terutama media massanya, cenderung telah memasukkan kata "jihad" dan "teroris", dalam satu kotak yang sama. Sebuah aksi yang kemudian dianggap berhasil.

Dengan demikian, korelasi antara politik Islam dan media cenderung menjadi negatif karena media justru dinilai sebagai alat untuk membuat stigma terhadap Islam. Relevan dikemukakan bagaimana pula media-media Islam ataupun jurnalis muslim menyikapi itu? Berkaitan dengan kondisi politik Islam dalam perspektif yang telah diurai di atas, maka media Islam maupun aktivis pers muslim, belumlah dapat dikatakan menjalankan fungsi integratif. Memang, dari satu sisi, komponen yang terbelah --yang di antaranya dapat dilihat dari tidak satunya partai-partai politik Islam serta organisasi keislaman yang beragam-- dianggap menjadi suatu masalah politik Islam tertentu yang begitu urgen.

\section{Hasil dan Pembahsan}

Pendapat yang mengatakan bahwa politik Islam bisa menunjukkan kemajuan berarti dalam memengaruhi kebijakan dan kekuasaan negara hanyalah dengan persatuan, bukanlah diajukan satu atau dua orang, melainkan banyak orang. Namun, dengan riwayat polarisasi Islam yang begitu panjang riwayatnya, integrasi umat Islam ini sendiri tampaknya hanya menjadi cita-cita, impian atau bahkan utopia yang tak berujung.

Beberapa aktivis Islam yang diwawancari menyebut, media yang lebih cenderung sekuler atau liberal, tentu akan sulit untuk menyatukan aliran. Apalagi aliran dalam Islam, baik untuk politik maupun keagamaan, bukanlah tunggal. Bila secara politik secara umum dapat dibedakan menjadi tiga model yaitu model liberal, demokrat dan fundamentalis, namun bila merujuk pada aliran berkeagamaan, jumlahnya akan semakin banyak. Apalagi bila diukur melalui skala organisasi dan paham masing-masing. Dalam hal itu, aktivis sendiri menyadari bahwa media dapat menjadi ruang untuk pikiran-pikiran, aktivitas Islam dan gerakan Islam.

Faktor pragmatisme dan vested interest dengan kekuasaan, seringkali dituding menjadi penyebab terbelahnya kekuatan politik itu. Tidak hanya dalam persoalan partai politik-partai politik yang ikut dalam pemilu legislatif, melainkan juga pentas pemilihan kepala daerah (Pilkada). Susahnya mendapatkan satu kesepakatan mengenai kandidat yang diusung menjadi satu tema besar yang tak berujung. Walau dalam beberapa kasus, ketika pilkada menghadapkan kandidat muslim dan non-muslim dalam sebuah pertarungan tunggal, kesamaan visi mengusung calon yang beragama muslim, agaknya lebih mudah dicapai. Hal ini terlihat ketika dalam Pilkada Kota Medan 2010 yang menghadapkan calon walikota muslim yaitu Rahudman Harahap dan calon walikota non-muslim, Sofyan Tan.

Karena vested interest dan pragmatisme itu, kalangan media juga melihat kepentingan politik aktivis dan partai Islam justru bukan mudah untuk disatukan. Itu masih diperkuat dengan fakta sejarah sejak masa pasca Pemilu 1955, partai-partai Islam justru mengalami faksi-faksi. Dengan berusaha menjalankan fungsi integratif, maka media massa jelas telah masuk dalam kancah pertarungan politik itu sendiri, alias menjadi "pemain". Dengan demikian, dia menjadi bagian penting dari politik Islam, walau dengan kerangka 
hasil akhir yang masih menjadi pertanyaan, objektif dari pertarungan itu sendiri tidaklah menyentuh pada sisi pertarungan ideologi negara, seperti yang dipertontonkan oleh mediamedia di masa konstituante yang begitu luas menjadi corong perubahan ideologi negara. Kalangan media umumnya, sudah menganggap selesai persoalan ideologi negara, Pancasila. Namun, faktor ketiadaan wacana "negara Islam" sebagai wacana di masa lalu, hanya salah satu indikasi. Pemerintahan pasca reformasi juga dinilai melanjutkan kekhawatiran pemerintahan sebelumnya terhadap ideologi Islam. Hal ini dapat dicontohkan dengan penutupan situs-situs online yang dikatakan membawa paham radikal dan fanatik. Ketiadaan badan hukum dan badan usaha media online sebagai argumentasi pemblokiran situs, dinilai sebagai sebuah standar ganda karena tidak diberlakukan secara merata kepada seluruh situs internet.

Realitas politik yang begitu kecil kemungkinan, maka seperti sudah dikatakan sebelumnya, pertarungan yang tersisa adalah mengisi struktur kekuasaan, baik di eksekutif maupun legislatif, walau menganggap persoalan ideologi sudah usai, kalangan media sendiri tidak terlalu terima bila dikatakan mereka tidak berani mengangkat atau mewacanakan soal ideologi negara menurut Islam, seperti yang terjadi di masa-masa sebelumnya. Apalagi, dengan keran keterbukaan di masa reformasi di mana media dan jurnalis dikatakan dapat menulis tentang "apa saja". Di antara argumentasi yang diajukan adalah ketiadaan narasumber media yang berbicara tentang ideologi negara Islam.

Betul bila dikatakan ada gerakan politik tertentu untuk menggolkan peraturan daerah (perda) syariah di beberapa kawasan terutama yang mayoritas Islam di Sumut, namun, hal itu sendiri pun tidak menjadi visi umum dari parpol dan organisasi keislaman yang berada di luar parlemen dan eksekutif. Soal perda syariah oleh kalangan media membedakan dengan jelas konsepsi itu dengan "negara Islam". Karena itu pula bisa disimpulkan bahwa derajat atau porsi suatu tema, tidaklah sama. Dengan demikian, perlakuan terhadap tema itu juga tidak sama.

Topik selanjutnya adalah rekrutmen dan institusionalisasi. Pola rekrutmen di media umum tidak berdasarkan faktor keagamaan ataupun latar belakang organisasi, namun, setidaknya meja dewan redaksi telah menjadi ladang pertarungan antara ideologi yang dibawa masing-masing wartawan sesuai latar belakangnya. Hal ini tampak pada pemberitaan peristiwa pembentukan Propinsi Tapanuli (Protap) dan dampak demonstrasi anarkis di Gedung DPRD Sumut beberapa waktu lalu, yang juga berimbas di meja redaksi yang dibawa oleh masing-masing reporter dengan pahamnya masing-masing. Pada even Pemilihan Kepala Daerah (Pilkada) hal-hal ideologis seperti itu juga terasa.

Beberapa jurnalis yang diwawancarai dalam studi ini menyebut kekurangan organisasi keislaman untuk melihat media pasca reformasi sebagai lahan perjuangan politik Islam yang baru di Sumut. Organisasi keislaman tidak menjadikan media sebagai salah satu tujuan dari kader-kadernya untuk beraktivitas. Dalam hal politik Islam, maka penyiapan kader justru lebih ditujukan di lapangan politik praktis. Lagipula, latar belakang wartawan pasca reformasi di media besar di Sumut, sebagian besar diperoleh dari pers mahasiswa atau pers kampus. Idealisme pers yang ditanam di sini bukanlah idealisme yang berdasarkan keagamaan tapi umum. Ini belum lagi merujuk pada rekrutmen jurnalis yang bukan produk dari pers mahasiswa yang tentu saja masih harus diselidiki lagi latarbelakang teknis dan ideologisnya.

Terkait itu, perlu juga disampaikan di sini, selain media-media yang berafilisasi pada parpol Islam di Pemilu 1955, tokoh-tokoh Islam sejak sebelum Indonesia merdeka, sebenarnya sudah mengambil jalur media untuk menyebarkan ide, pemikiran, peristiwaperistiwa keislaman, termasuk politik. Hal ini tampak pada tabel di bawah ini. 
Vol 1 No. 2, 2019, 1-10

DOI: https://doi.org/10.30596/persepsi.v2i2.393710

Tabel 1. Media Terbitan Organisasi Keislaman

dan Tokoh-tokoh Islam Kurun 1910-1966

\begin{tabular}{|c|c|}
\hline ORGANISASI/TOKOH & NAMA MEDIA \\
\hline Muhammadiyah & $\begin{array}{l}\text { Soeara Muhammadijah (1955), Penyiar Islam, Pancaran Amal, } \\
\text { Almanak Muhammadiyah, Suara Aisyiyah, Mertju Suar }\end{array}$ \\
\hline Persis & $\begin{array}{l}\text { Pembela Islam (1929), Al-Fatwa (1931), Al-Lissan (1935), At- } \\
\text { Taqwa (1937), Al-Hikam (1939), Aliran Islam (1948), Risalah (1962) }\end{array}$ \\
\hline Jami'atul Al-Washliyah & $\begin{array}{l}\text { Medan Islam (1933), Raudhatul Muta'allimin (1937), Dewan Islam } \\
\text { (1938) }\end{array}$ \\
\hline NU & Berita NU, Duta Masyarakat \\
\hline Al-Ittihadiyah & Al-Hidayah \\
\hline Syarikat Ilmu & Al-Munir (1911-1915). Terbit di Padang \\
\hline Sumatra Thawalib & Al-Munir Al-Manar (1918-1924), terbit di Padang Panjang \\
\hline Sain al-Maliki & Dunia Akhirat (1923-1925), terbit di Bukit Tinggi \\
\hline Syekh Haji Abbas Padang Japang & Al-Imam (Payakumbuh) \\
\hline Pelajar Islam Indonesia (PII) & Islam Bergerak \\
\hline Surabaya & Al-Jihad, Al-Islam \\
\hline Peranakan Arab Indonesia & Aliran Baru \\
\hline $\begin{array}{l}\text { Abdul Wahid } \\
\text { KH Abdul Madjid Abdullah }\end{array}$ & Suluh Islam (Medan) \\
\hline HR Rasuna Said & Menara Putri (Medan) \\
\hline H Bakri, Bakhtiar Yunus & Sinar (Medan) \\
\hline $\begin{array}{l}\text { Hamka, } \\
\text { Mohammad Yunan Nasution }\end{array}$ & Pedoman Masyarakat (Medan) \\
\hline Zainal Abidin Ahmad & Panji Islam (Medan) \\
\hline $\begin{array}{l}\text { KH Fakih Usman, Hamka, Yusuf } \\
\text { Abdullah Puar }\end{array}$ & Panji Masyarakat (1959) \\
\hline Mas Mansoer & Suara Santri \\
\hline Hamka & Al-Basyir \\
\hline$n / a$ & $\begin{array}{l}\text { 1. Terbit di Padang dan beberapa kota di Sumatera Barat): Medan } \\
\text { Rakyat, Matahari Islam, Tafsir Quran, Al-bayan, Al-Itqan } \\
\text { 2. Bandung: Pembangkit, Al-Hidayah, Aliran Muda } \\
\text { Terbit di Bandung } \\
\text { 3. Samarinda: Persatoean }\end{array}$ \\
\hline
\end{tabular}

Sumber: Heri Ruslan (Heri Ruslan, 2012) dan berbagai sumber

Bandingkan pula dengan riuhnya partai politik di Indonesia sejak masa pemerintahan Sukarno yang mengambil media massa sebagai salah satu ornamen perjuangan bagi ideologi politik masing-masing.

Tabel 2. Media dan Partai Politik di Masa Demokrasi Terpimpin

\begin{tabular}{|l|l|l|}
\hline MEDIA & PARTAI POLITIK & KETERANGAN \\
\hline $\begin{array}{l}\text { Bintang Merah (1945), Harian Rakjat } \\
\text { (1951) }\end{array}$ & PKI & $\begin{array}{l}\text { Majalah dan Koran Resmi } \\
\text { PKI. Harian Rakjat terdiri } \\
\text { dari 14 afiliasi }\end{array}$ \\
\hline $\begin{array}{l}\text { Sin Po/Warta Bakti (Jakarta); Trompet } \\
\text { Masyarakat (Surabaya) }\end{array}$ & & $\begin{array}{l}\text { Bersifat simpatisan terhadap } \\
\text { PKI (dibredel 1965) }\end{array}$ \\
\hline $\begin{array}{l}\text { Bintang Timur } \\
\text { Abadi (1947-1960) }\end{array}$ & Partindo & \\
\hline Pedoman (1948) & Masyumi & Dinilai cenderung pada PSI.
\end{tabular}


Vol 1 No. 2, 2019, 1-10

DOI: https://doi.org/10.30596/persepsi.v2i2.393710

\begin{tabular}{|l|l|l|}
\hline & & Dibredel pada 1961. \\
\hline Suluh Indonesia (1953) & PNI & 8 afiliasi \\
\hline Duta Masjaraka, Duta Revolusi & NU & 7 afiliasi \\
\hline Api Pantjasila & IPKI & 3 afiliasi \\
\hline Nusa Putera (1964-1965) & PSII & \\
\hline Sinar Bakti & Partai Katolik & 4 afiliasi (tidak terbit) \\
\hline Fadjar Baru & $\begin{array}{l}\text { Persatuan Tarbiyah } \\
\text { Islamiyah (Perti) }\end{array}$ & 1 afiliasi \\
\hline n/a & Parkindo & 2 afiliasi media \\
\hline Sumber: Diramu dari berbagai sumber & & \\
\hline
\end{tabular}

Kalangan aktivis Islam yang diwawancari dalam studi ini mengakui kekurangan tersebut. Ketiadaan media sekaligus minimnya pelatihan jurnalistik dalam berbagai level di organisasi keislaman, kemahasiswaan maupun kepemudaan Islam, membuat ketiadaan orientasi bagi umat Islam untuk secara khusus memasuki kawasan dan institusi jurnalistik di Indonesia dan Sumut pada khususnya, meski organisasi keislaman sendiri bukannya tidak serius soal itu karena di beberapa organisasi juga ada semacam divisi yang mengurusi soal komunikasi dan informasi, namun namun cenderung tidak menjadikan jurnalistik sebagai sebuah strategi dakwah. Artinya, program seperti itu justru memang tidak eksis. Ini sangat berbeda dengan penyiapan kader (kaderisasi) lembaga untuk masuk ke partai-partai politik. Karena itu pula, asupan jurnalis Islam di media-media umum, kurang dibarengi dengan pemahaman Islam yang kukuh dan mendalam, namun lebih umum dan sekuler. Bahkan, dari wawancara informal yang dilakukan terhadap sejumlah jurnalis muda, menyebutkan bahwa konsepsi perjuangan Islam lewat media justru adalah hal yang tidak terlalu akrab alias asing. Itulah makanya, bila ada pendapat yang mengatakan pergerakan politik Islam di tubuh media, kurang lebih hanya bersifat sporadis dan tidak terstruktur.

\section{Kesimpulan}

Diskursus politik Islam di media merupakan gambaran definisi dan pemaknaan politik Islam di kalangan media maupun aktivis sosial politik Islam di Sumut, yang secara garis besar terbelah pada pemahaman holistik dan sekuler, baik radikal maupun moderat. Selain itu, konflik yang terjadi antara negara maupun penyelenggara negara terhadap media dan Islam, tidak hanya diakibatkan oleh kepentingan politik yang bersifat prinsip ideologis seperti perubahan dasar negara, tapi juga oleh pragmatisme kekuasaan dan ekonomi di kalangan media dan aktivis Islam. Ini memengaruhi substansi konten dari media.

Kebijakan media dan pemilik merupakan dasar proses dan produk jurnalistik di tingkat jajaran redaksional. Ketiadaan media yang berkonsentrasi pada politik Islam, dan lebih memilih segmentasi umum-sekuler, membuat agenda politik Islam tergantung pada pertimbangan ideologis pemilik dan pilihan segmentasi pasar. Selain itu, program khusus terstruktur dan sistematis yang berkonsentrasi di bidang jurnalisme Islam di organisasi dan partai keislaman, sangat minim, sporadis, tak terjadwal, dan tidak mempunyai output tertentu soal media dan politik Islam. Sehingga, media umum yang lebih sekuler menguasai penyebaran wacana dan informasi. Padahal, media diakui sangat penting untuk kekuatan politik Islam. Meski, harus digarisbawahi bahwa dalam kasus-kasus peristiwa tertentu, media yang menjaga segmentasi sosiologis berdasarkan keagamaan, dan juga jurnalis yang beragama muslim, tetap menunjukkan keberpihakannya terhadap politik Islam dalam proses aktivitas jurnalistik di lapangan, maupun di sidang dewan redaksi. 


\section{Daftar Pustaka}

Anto, J., dkk. (2005). Pers Bebas, Tapi Dilibas; Cermin Retak Kebebasan Pers di Sumatera \& Aceh. Medan: KIPPAS.

Badan Pusat Statistik. (2010). Kewarganegaraan, Suku Bangsa, Agama dan Bahasa Sehari-hari Penduduk Indonesia: Hasil Sensus Penduduk 2010. Jakarta: Badan Pusat Statisik.

Effendy, Bahtiar. (1998). Islam dan Negara: Transformasi Pemikiran dan Praktik Politik di Indonesia. Jakarta: Paramadina.

Eriyanto. (2005). Analisis Framing Konstruksi Ideologi dan Politik Media. Yogyakarta: LkiS.

Kuntowijoyo. (2008). Paradigma Islam: Interpretasi untuk Aksi. Bandung: Mizan.

McQuail, Dennis. (1991). Teori Komunikasi Massa: Suatu Pengantar.Edisi Kedua. Jakarta: Erlangga.

Miles, Matthew B. dan A. Michael Huberman. (1992). Analisis Data Kualitatif: Buku Sumber Tentang Metode-metode Baru. Jakarta: UI Press.

Ruslan, Heri. (2012). "Hikayat Media Massa Islam di Nusantara,". Selasa 10 April 2012. (https://www.republika.co.id/berita/dunia-islam/khazanah/12/04/10/m297o9hikayat-media-massa-islam-di-nusantara), diakses 20 September 2019.

Sudibyo, Agus. (2006). Politik Media dan Pertarungan Wacana. Yogyakarta: LKiS.

The Union of News Agencies (UNA). (http://www.iinanews.com/page/ public/page.aspx?page_ID=1) diakses 30 September 2019.

Tim Dewan Pers.(2012). Data Pers Nasional 2012. Jakarta: Dewan Pers. 